\title{
Desain dan Evaluasi Pembelajaran Blended Learning Berbasis Whatsapp Group (WAG)
}

\author{
Miksan Ansori \\ Sekolah Tinggi Ilmu Syari'ah Faqih Asy'ari Kediri, Indonesia \\ Email: Ikhsan.aira@gmail.com
}

\begin{abstract}
Abstraksi
Blended learning as one of the $21^{\text {st }}$ century learning always interesting to be discused more deeply. The extend of blended learning scope so the study never dries. Many sides need more critical dan detailed discussion in order to give a stronger perspective, to enrich the science of blended learning and become the reference of education practicioners in practicing it.

This article discusses the design and evaluation of blended learning using WhatsApp Group (WAG) application in the context of learning in college. Design will contain learning activities and media used. While the evaluation is intended to determine the result of blended learning in achieving learning objectives. Detailed activities to give a detailed perspective of how blended learning is applied. Keywords: design, evaluation, blended learning, WhatsApp Group (WAG)
\end{abstract}

\section{Pendahuluan}

Artikel ini membahas blended learning menggunakan aplikasi Whatsapp. Khususnya desain dan evaluasi pembelajaran dalam konteks tingkatan di perguruan tinggi. Sejak awal 1990, Konsep online learning membentuk kemungkinan adanya blended learning. ${ }^{1}$ Sejak saat itu pula kajian online learning berkembang sedemikian rupa hingga berintegrasi dengan pembelajaran dalam kelas. Hal itu bisa dimaklumi mengingat seseorang cenderung akan mengombinasikan pengetahuan baru yang didapatnya dengan pengetahuan yang telah dimilikinya sebelumnya. ${ }^{2}$

Saat ini telah berkembang dengan pesat kajian mengenai blended learning. Bentuk paling sederhana dari blended learning, menurut Garrison dan Kanuka adalah perpaduan antara aktivitas kelas fisik dan aktivitas belajar yang didukung oleh

\footnotetext{
${ }^{1}$ P. M. Senge, The Fifth Discipline: The Art and Practice of the Learning Organization. (New York: Doubleday, 1990), 26.

${ }^{2}$ Mauri. Collins dan Zane Berge, Facilitating Interaction in Computer Mediated Online Course. Proceedings of the FSU/AECT Conference on Distance Learning . Juni 20-23, Tallahassee, Florida. 1
} 
teknologi daring ${ }^{3}$, dan kemudian berkembang lebih lanjut dalam integrasi aktivitas pembelajaran, peserta didik, dan pendidik. Manfaat dari blended learning telah diungkap dalam banyak penelitian, antara lain dalam proses memfasilitasi pembelajaran online maupun yang berbasis kelas ${ }^{4}$, menjembatani jarak antara belajar dan bekerja ${ }^{5}$, mempromosikan pembelajaran kolaborasi online ${ }^{6}$, sesuai untuk pembelajaran di perguruan tinggi ${ }^{7}$, efektivitas kelompok besar siswa serta beragam ${ }^{8}$, Mampu beradaptasi untuk semua jenjang pembelajaran dan banyak institusi termasuk perguruan tinggi ${ }^{9}$, sekolah menengah ${ }^{10}$, militer $^{11}$ dan banyak sektor lainnya.

Akan tetapi permasalahannya adalah blended learning tidak dikenalkan dengan baik. Argumentasi yang dikemukakan adalah bahwa perkembangan profesionalisme secara umum dikarenakan banyaknya literatur yang disampaikan oleh guru ahli yang berfokus pada bagaimana seorang guru memahami materi dan bagaimana seorang guru memahami cara siswa mempelajari sebuah materi. Blended learning belum dipandang sebagai sebuah alternatif lain yang inovatif dan mampu menggeser

${ }^{3}$ Randy Garrison dan Heather Kanuka, Blended Learning: Uncovering its Transformative Potential in Higher Education. Internet and Higher Education Journal. Vol 7 No. 2, 2004, 95-105.

${ }^{4} \mathrm{~N}$. Vaughan, Perspectives on Blended Learning in Higher Education. Internasional Journal on ELearning. Vol. 6, No.1 (2007), 81-94.

5 K. Bohle-Carbonell, dkk. Supporting learner engagement through Problem-based learning: Institutional and instructional implications. In P. Blessinger \& C. Wankel (Eds.), Increasing student engagement and retention in e-learning environments: Web 2.0 and blended learning technologies (Vol. 7). (NY: Emerald, 2013).1-15

${ }^{6}$ A. Carr-Chellman, D. Dyer, \& J. Breman, Burrowing through the Network Wires: does Distance Detract from Collaborative Authentic Learning? Journal of Distance Education, Vol.15. No.1. 2000, 39-62.

${ }^{7}$ Garison. Lended Learning., 95-105

${ }^{8}$ C. D. Dziuban, J. L. Hartman, \& P. D. Moskal, Blended Learning. Educause Center for Applied Research: Research Bulletin, (2004, March 30), 1-12, diunduh dari http://net.educause.edu/ir/library/pdf/ERB0407.pdf .; Baca juga R. Sharpe, G. Benfield, G. Roberts, \& R. Francis, the Undergraduate Experience of Blended e-Learning: a Review of UK Literature and Practice. The Higher Education Academy, Diunduh dari http://www.heacademy.ac.uk/assets/documents/research/literature reviews/blended_elearning_exec summary 1.pdf.

9 A. Kaur, \& A. Ahmed, Open Distance Pedagogy: Developing a Learning Mix for the Open University Malaysia. In C. Bonk \& C. Graham (Ed.), The Handbook of Blended Learning. (San Francisco, CA: Pfeiffer, 2005), 311-264.

${ }^{10}$ J. B. Keller, L. H. Ehman, \& C. Bonk, Professional Development that Increases Technology Integration by K-12 Teachers: Influence of the TICKIT Program. Paper presented at the annual meeting of the American Educational Research Association (San Diego: CA, 2004), 12.

${ }^{11}$ C. J. Bonk, T. M. Olson, R. A. Wisher, \& K. L. Orvis, Learning from focus groups: An examination of blended learning. Journal of Distance Education, Vol. 17, No.3 (2002), 97-118. 
paradigma lama tersebut ${ }^{12}$. Beberapa temuan juga mengungkapkan bahwa blended learning termasuk membahayakan konsep belajar ${ }^{13}$.

Kajian mengenai blended learning akhirnya menghasilkan bermacam kesimpulan seperti manfaat, problematika dan bahkan definisi dari blended learning tidak dapat diikat persetujuan secara umum. Kajian blended learning yang menggambarkan secara jelas dan baik juga diperlukan. Selain akan memberikan perspektif yang gamblang, juga akan memberikan keyakinan bahwa blended learning memungkinkan untuk diaplikasikan dalam sebuah pembelajaran. Kajian blended learning yang spesifik dalam sebuah model tertentu meskipun akan terjebak dalam sebuah kondisi pada suatu titik, namun penjabarannya akan memberikan ruang untuk mengambil nilai-nilai yang mudah untuk dikembangkan dan dimodifikasi sesuai konteks pembelajaran yang diinginkan peneliti maupun praktisi pendidikan lainnya.

\section{Definisi Blended Learning}

Blended learning pada dasarnya adalah suatu sistem belajar yang memadukan antara belajar secara face to face (bertemu muka/klasikal) dengan belajar secara online (melalui penggunaan fasilitas/media internet). Ada beberapa pendapat yang berbeda dari para ahli dalam menentukan persentase untuk masing-masing cara, baik itu yang sifatnya face to face atau online. Sloan menyebutkan bahwa sebuah pembelajaran dikatakan menggunakan strategi blended learning apabila 30-80\% dari desain dan implementasi pembelajaran baik dalam hal isi maupun penyampaiannya dilakukan secara online. ${ }^{14}$

Sementara itu Rob Hubbart mengungkapkan bahwa:

Blended learning is the combination of different training 'media' (technologies, activities and types of events) to create an optimum training program for a specific audience. The term 'blended' means the traditional instructor-led training is being supplemented with other electronic formats. Blended Learning is a mixing of different learning environments. It combines traditional face to-face classroom methods with more modern computer-mediated activities. According to its proponents, the strategy creates a more integrated approach for both instructors and learners. Formerly, technology-based materials played a supporting role to face-to-face instruction. ${ }^{15}$

\footnotetext{
12 Vaughan, Perspectives on., 81-94.

${ }^{13}$ C. Seife, Zero: The Biography of a Dangerous Idea. (New York: Penguin Books, 2000).

${ }^{14}$ Maria D. Avgerinou, Blended Collaborative Learning for Action Research Training. Journal of Open Education, Vol 4, No.1, 2008, 88.

${ }^{15}$ Ibid, Rob, The Really Useful, 93.
} 
Rob Hubbart dalam definisi tersebut, mengartikan lebih luas lagi mengenai blended learning. Pembelajaran blended learning tidak hanya sebatas pada kombinasi antara face to face learning dan on line learning, akan tetapi juga kombinasi antara berbagai media pembelajaran seperti kombinasi berbagai teknologi, aktivitas dan juga kombinasi berbagai lingkungan belajar. Bonk dan Graham juga mengamini pendepat tersebut, dan menyatakan bahwa definisi blended leaning umumnya memuat:

a. The combination of instructional modalities or delivery media and technologies.

b. The combination of instructional methods, learning theories, and pedagogical dimensions.

c. The combination of online learning and face-to-face learning. ${ }^{16}$

Kombinasi dari berbagai unsur tersebut, baik media dan teknologi, teori, strategi dimensi pembelajaran maupun face to face learning dan online learning memungkinkan cakupan blended learning yang lebih luas. Sehingga pengajar atau perancang pembelajaran dapat berkreasi memilihi kombinasi yang paling sesuai dengan kondisi peserta didik dan lingkungan belajar yang dihadapinya.

Blended learning juga biasa disebut hybrid learning, karena memadukan keunggulan-keunggulan yang dimiliki model pembelajaran tradisional dan manfaatmanfaat yang ada pada pembelajaran online dalam menyajikan pembelajaran yang lebih berpusat pada peserta didik serta mampu menyesuaikan karakteristik dan kebutuhannya. Peserta didik yang sebelumnya hanya mendapat pembelajaran konvensional berbasis tatap muka dengan segala keterbatasannya, maka dengan blended learning peserta didik akan mampu meningkatkan kualitas pembelajarannya melalui setiap karakteristik positif pembelajaran online.

Terdapat tiga landasan perubahan pengaruh online learning dalam proses pembelajaran, yaitu pergeseran filosofi dari objektivisme menjadi konstruktivisme, pergeseran teoritis dari pandangan behaviorisme menjadi pandangan sosio-kognitif dan pergeseran pedagogis dari pembelajaran langsung menjadi pembelajaran kolaboratif. ${ }^{17}$ Pergeseran paradigma yang melandasi blended learning tersebut tentu dalam praktiknya akan sangat mempengaruhi perkembangan implementasi model pembelajaran tersebut dikarenakan kemampuannya beradaptasi terhadap perubahan zaman.

16 Al-Huneidi Ahmad, Constructivism Based Blended Learning in Higher Education, Tesis, (Wetenschappen: Universiteit Hasselt Faculteit Toegepaste Economische, 2010), 8.

${ }^{17}$ Bonk dan Graham, Handbook of Blended Learning: Global Perspective, Local Design (Cheicester: John Wiley \& Sons Inc, 2004), 48. 
Blended learning juga harus dipandang sebagai pendekatan pembelajaran yang memadukan keunggulan efektivitas dan unsur sosial yang dimiliki face to face learning dengan pembelajaran aktif berbasis teknologi yang dimiliki pembelajaran online. Bahkan lebih jauh lagi, blended learning seharusnya tidak digunakan sebagai pembelajaran yang sifatnya temporal, akan tetapi harus dipertimbangkan sebagai desain dasar dalam pengembangan model pembelajaran. Hal itu didasari pada integrasi teknologi dalam kehidupan yang semakin pesat yang menyentuh tiap lini kehidupan termasuk dalam pendidikan. Perkembangan teknologi juga telah menyentuh elemen pengajar dan peserta didik dan bahkan telah menjadi kebutuhan bagi setiap orang termasuk objek dan subjek dalam pembelajaran. Tentu saja paduan antara online learning dan face to face tidak bisa dibatasi berapa persen perbandingan penggunaannya. Akan tetapi, dengan tetap melibatkan pembelajaran daring dalam kegiatan belajar mengajar, menjadikan proses pembelajaran lebih berkualitas, fleksibel, meningkatkan partisipasi belajar peserta didik serta memudahkan pencapaian tujuan pembelajaran yang telah dirumuskan.

Perpaduan online learning dan face to face learning dalam blended learning ditujukan untuk mengambil kelebihan yang dimiliki masing-masing model pembelajaran dari keduanya.

Dalam pembelajaran online learning, tentu harus dipakai sebuah perangkat lunak maupun perangkat keras yang digunakan untuk mendukung terselenggaranya online learning sebagai bagian dari blended learning. Salah satu bentuk perangkat lunak yang dapat digunakan adalah dengan aplikasi Whatsapp. Aplikasi ini merupakan salah satu bentuk perangkat lunak yang digunakan sebagai media sosial yang menghubungkan banyak orang dalam sebuah komunikasi audio-visual dan juga didukung kemampuan chat yang relatif cepat bila dibandingkan aplikasi lainnya misalkan BBM, FB Masangger atau Yahoo Mesengger. Keunggulan aplikasi Whatsapp lainnya antara lain yaitu:

a) Banyak digunakan terutama oleh kalangan mahasiswa (pengguna Whatsapp di seluruh dunia yaitu lebih dari 1 milyar orang)

b) Mudah diinstall dalam program smartphone (hanya butuh beberapa tahap dalam penginstalannya)

c) Data instalasi sangat ringan (Bila menggunakan playstore kurang lebih $18 \mathrm{Mega}$ Bytes saja untuk mengunduh aplikasi Whatsapp)

d) Dapat dibuat grup untuk komunitas tertentu (user Whatsapp banyak yang membuat grup dengan latar belakang tertentu, misal grup alumni sekolah, grup rekan kerja, grup teman satu kelas dan lain sebagainya) 
e) Akselerasi chatting yang relatif tinggi (banyak user menggunakan aplikasi Whatsapp karena kecepatannya dalam mengirim pesan)

f) Dapat digunakan untuk mengirim file, picture, pesan suara, video, GPS, kiriman web/link, emoji dan lain sebagainya

g) Dalam teks Whatsapp juga dapat digunakan fitur huruf tebal (bold), huruf miring (italic) dan underline yang sangat bermanfaat misal untuk penegasan kata dan penegasan istilah tertentu.

h) Dapat mengetahui status penerima pesan, yaitu satu centang putih untuk tanda pesan pending, dua centang putih berarti pesan sudah diterima dan belum dibaca/dibuka, dan dua centang biru sebagai tanda pesan sudah diterima dan dibaca.

Semua hal positif yang dimiliki aplikasi Whatsapp tersebut pada dasarnya adalah sebagai bentuk upaya memfasilitasi pembelajaran yang optimal. Dalam prinsip teknologi pendidikan, facilitating learning diarahkan untuk menumbuhkan pemahaman bagi peserta didik di mana peserta didik memiliki ruang relatif untuk mengontrol, menguasai dan merasa memiliki pembelajaran itu sendiri. ${ }^{18}$ Di samping dengan aplikasi Whatsapp sebagai media utama pembelajaran online, media pendukung lain juga dapat digunakan. Misalkan, blog Wordpress sebagai rangkuman dan rujukan materi yang diajarkan, Youtube sebagai rujukan video yang lebih memiliki cakupan yang luas dan variatif, Wikipedia untuk mengetahui teori dan konsep serta definisi umum terkait dengan materi yang digunakan, serta portal media berita berbasis online untuk mendukung berita aktual terkait dengan materi pembelajaran (seperti tempo.co, detiknews.com, liputan6.com dan lain sebagainya).

\section{Manfaat blended learning dalam pembelajaran}

Keberhasilan blended learning haruslah berisi kombinasi dari media-media yang mendukung pembelajaran dan menciptakan pembelajaran yang berkualitas dengan biaya yang serendah mungkin. Penentuan media apa yang sesuai untuk digunakan tergantung dari beberapa faktor seperti kemampuan peserta didik dalam menggunakan IT, tujuan pembelajaran, sarana prasarana yang dimiliki dan lain sebagainya. Kenyataannya, karakteristik peserta didik yang berbeda mempengaruhi gaya belajar setiap peserta didik, dan blended learning merupakan bentuk pembelajaran yang memungkinkan peserta didik untuk belajar sesuai gaya belajar

\footnotetext{
${ }^{18}$ Rhonda Robinson dkk. "Facilitating Learning", dalam Educational Technology: A Definition with Commentary, ed. Alan Januszewski dan Michael Molenda (New York: Taylor \& Francis Group, 2008), 41.
} 
mereka sendiri sehingga dapat meningkatkan efektivitas kegiatan belajar mengajar dan tingkat keberhasilan pencapaian tujuan pembelajaran.

Terdapat beberapa manfaat yang dimiliki blended learning, yaitu:

a. Fleksibel

Satu model pembelajaran saja akan terbatas dalam pencapaian pengetahuan dan pengalaman belajar bagi peserta didik. Dalam pembelajaran tradisional (face to face atau classroome based learning) akses untuk pengetahuan dan pengalaman belajar dibatasi hanya pada peserta didik yang dapat hadir di waktu dan tempat tertentu. Sedangkan online learning dapat dijangkau peserta didik di mana pun dan kapan pun. Blended learning menghadirkan keseimbangan pembelajaran antara fleksibilitas dan pengalaman interaksi siswa dengan memadukan face to face learning dan online learning.

b. Meningkatkan kualitas belajar

Salah satu manfaat utama dalam blended learning adalah efektivitas praktik pembelajaran. Blended learning dapat meningkatkan level interaksi belajar dan aktivitas belajar siswa dan pada akhirnya dapat meningkatkan sharing pengetahuan antar peserta didik atau pengajar, kolaborasi antar peserta didik, meningkatkan kemampuan menyelesaikan masalah dan menambah pengalaman belajar yang inovatif.

c. Hemat waktu dan biaya

Kombinasi yang ada pada blended learning sangat memungkinkan terjadinya penghematan biaya dan waktu. Di satu sisi, jika hanya menerapkan pembelajaran online, maka dana untuk mendapatkan jaringan internet akan sangat mahal. Sedangkan di sisi lain, dalam face to face learning juga akan membutuhkan biaya yang tidak sedikit pula di samping tenaga yang harus digunakan jika setiap peserta didik diharuskan bertemu pada waktu dan tempat tertentu. Perpaduan kedua tipe pembelajaran tersebut akan lebih meningkatkan hasil belajar peserta didik dengan perpaduan strategi dan media pembelajaran yang paling efektif dan efisien. Blended learning juga dapat meningkatkan pengetahuan dan keterampilan tanpa dibatasi waktu dan tempat dengan memilih tipe model blended learning sesuai dengan konteks keadaan di mana proses pembelajaran berlangsung.

\section{Model pembelajaran blended learning}

Blended learning didasarkan pada prinsip belajar yang berkelanjutan dan bersifat fleksibel. Berdasarkan hal itu maka, blended learning memiliki bentuk 
pembelajaran yang variatif pula. Variasi blended learning memungkinkan pengajar maupun peserta didik untuk tetap dapat melakukan proses belajar dalam kondisi apapun dan tidak hanya berhenti pada pembelajaran di ruang kelas saja. Para ahli secara umum menyatakan bahwa terdapat empat model blended learning, yaitu:

a. Face to face driver model. Model driver tatap muka digunakan mana kala teknologi digunakan hanya sebagai pendukung dalam pembelajaran tradisional. Jadi pembelajaran berbasis kelas tetap merupakan pembelajaran utama, dan online learning hanya sebagai suplemen untuk melengkapi pembelajaran.

b. Rotation Model. Model ini merupakan kombinasi terstruktur model pembelajaran face to face dan pembelajaran online. Terstruktur maksudnya adalah, antara pembelajaran face to face dan pembelajaran online sudah memiliki jadwal sendiri. Sesi untuk pembelajaran face to face sudah ditentukan dan sesi pembelajaran online juga telah ditentukan. Dalam model ini, ke dua tipe pembelajaran benar-benar dipisahkan dan tidak ada integrasi antara satu dengan yang lainnya.

c. Flex model. Model pembelajaran blended learning ini memusatkan pada pembelajaran mandiri kepada peserta didik melalui online learning. Jadi pengajar telah menentukan fokus-fokus pembelajaran beserta haluan-haluan pembelajaran untuk dilaksanakan peserta didik saat mereka melaksanakan pembelajaran daring. Pengajar dalam model blended learning ini hanya sebagai fasilitator. Terkadang juga menggunakan pembelajaran tatap muka jika dibutuhkan.

d. Online lab school model. Model blended learning ini merupakan pembelajaran yang dilakukan dalam ruang laboratorium digital dan sepenuhnya menggunakan pembelajaran online. Pengajar hanya sebagai fasilitator serta memandu jalannya proses pembelajaran dalam laboratorium tersebut. Perbedaannya dengan flex model terletak pada tempat di mana blended learning tersebut dilaksanakan. Flex model tidak dibatasi harus dalam laboratorium digital, sedangkan online lab school model dilaksanakan dalam sebuah labaratorium yang dioptimalkan untuk mendukung pembelajaran online.

Sedangkan Adam dan Morgan yang telah menerapkan blended learning dalam penelitiannya, membedakan blended learning dalam empat bentuk, namun dengan kategori yang berbeda, sebagai berikut:

a. Model I : Model ini pada dasarnya adalah model pembelajaran tatap muka, sedangkan online learning hanya digunakan sebagai sumber pendukung saja. Bentuk online learning dalam model ini sangat terbatas seperti pencarian sumber referensi materi pembelajaran atau sumber bacaan tambahan saja. Materi online sifatnya hanya suplemen, oleh karenanya jika tidak ada materi tersebut, 
pembelajaran tetap dapat berlangsung. Terbatasnya penggunaan materi online juga bisa dimaknai pada terbatasnya peserta didik yang memanfaatkan materi tersebut. Artinya tidak semua peserta didik memanfaatkan materi online, karena bisa jadi hanya sedikit saja peserta didik yang dapat mengakses materi online disebabkan terbatasnya sarana dan prasarana pendukung.

b. Model II : Model ini menyeimbangkan online learning dan classroom instruction. Online learning digunakan sebagai syarat terselenggaranya pembelajaran tatap muka atau sebaliknya. Hasil belajar dari model ini sangat ditentukan oleh beberapa hal. Misalkan, aktivitas pra-pembelajaran dapat menjadikan peserta didik lebih siap dalam kegiatan belajar-mengajar sedangkan aktivitas pasca pemelajaran dapat memperdalam pemahaman dan memperluas pengetahuan tentang materi pembelajaran yang telah diberikan.

c. Model III : Pada model ini face to face learning dan online learning sangat erat hubungannya dengan tujuan belajar setiap individu. Hasil belajar (kognitif, afektif dan psikomotorik) akan tinggi jika terdapat akuntabilitas yang jelas dan nyata kepada siswa dalam mengintegrasikan teori dan praktik. Model ini akan berjalan sukses jika sumber-sumber belajar online ditetapkan dengan jelas sebagai syarat tindak lanjut pembelajaran tatap muka. Misalkan saja adalah dengan memberikan tugas melengkapi lembar kerja dengan topik tertentu, atau peserta didik diberikan tugas untuk menelaah suatu topik kemudian dilaporkan dalam bentuk tulisan atau kata-kata.

d. Model IV : Strategi belajar yang diterapkan dalam model ini dirancang dengan pendekatan produk hasil belajar baik secara individu atau kelompok. Tatap muka dan daring difokuskan pada hasil belajar positif melalui sebuah produk belajar, di mana kinerja individu atau tim merupakan tujuan utama pembelajaran. Hasil belajar yang ditunjukkan dalam model ini sangat tergantung dari peserta didik. Jika peserta didik memiliki keseriusan dalam mengerjakan tugas yang diberikan maka, hasil belajar yang diperoleh akan maksimal, begitu juga sebaliknya. Face to face learning seperti, pengajaran, evaluasi, penilaian harus digunakan sebagai pendukung agar tugas yang diberikan dapat terlaksana dengan baik dan tujuan pembelajaran dapat tercapai dengan maksimal bagi setiap peserta didik.

\section{Desain aktivitas pembelajaran blended learning.}

Menciptakan lingkungan belajar dan aktivitas pembelajaran untuk mencapai tujuan pembelajaran merupakan dua hal penting dalam suatu desain pembelajaran. Sering kali tujuan pembelajaran tidak dapat tersampaikan dengan optimal dikarenakan 
lingkungan belajar dan aktivitas pembelajaran yang tidak didesain dengan baik. Perencanaan keduanya merupakan pengembangan interaksi antara peserta didik dan materi pembelajaran agar peserta didik tersebut memperoleh pengetahuan, pandangan dan ketrampilan baru.

Hendaknya lingkungan belajar dan aktivitas belajar yang diciptakan bersesuaian dengan kebutuhan peserta didik, karakteristik peserta didik, rumusan tujuan pembelajaran dan materi pembelajaran yang telah dianalisis dan ditetapkan sebelumnya. Misalkan saja aktivitas diskusi dalam kelas yang peserta didiknya masih pada tingkat sekolah dasar akan sulit mencapai tujuan pemelajaran yang diinginkan karena wawasan peserta didik masih sangat terbatas untuk berdiskusi. Contoh lainnya adalah ketika pembelajaran yang memiliki tujuan agar siswa fasih membaca al Qur'an, maka desain aktivitas pembelajaran yang sesuai yaitu dengan praktik membaca al Qur'an secara langsung bukan sekedar belajar teori-teorinya saja.

Tentu saja banyak sekali aktivitas pembelajaran yang sudah dicetuskan beberapa ahli dan praktisi. Pengajar dapat memilih aktivitas pembelajaran yang sesuai dengan kebutuhan dan karakteristik peserta didik serta tujuan dan materi pembelajaran yang ada. Pengajar tidak harus menerapkan secara penuh konsep aktivitas pembelajaran dari para ahli, namun bisa saja memodifikasinya sesuai kebutuhan dan konteks pembelajaran yang akan dilaksanakannya.

Dalam mendesain pembelajaran blended learning dengan aplikasi Whatsapp. kebutuhan peserta didik diutamakan pada aspek kenyamanan belajar yang bisa terealisasikan dengan blended learning. Sebab peserta didik diberi kendali yang cukup besar sesuai dengan gaya belajar dan karakteristik yang dimilikinya. Blended learning juga relevan dengan kondisi peserta didik di perguruan tingi saat ini yang banyak menggunakan aplikasi Whatsapp sebagai salah satu alat telekomunikasinya seharihari.

Blended learning dapat menciptakan aktivitas belajar baru yang memberikan situasi belajar baru yang belum banyak praktikkan sebelumnya. Banyak ahli dan praktisi juga telah membuktikan efektivitas penerapan blended learning dalam pencapaian tujuan pembelajaran. Aktivitas pembelajaran dengan Blended learning juga bersesuaian dengan materi pembelajaran yang akan disajikan, yaitu dalam bentuk teks, video, audio, ceramah terkait topik bahasan perkuliahan. Dengan Blended learning diharapkan peserta didik tidak hanya mencapai tujuan khusus pembelajaran yang telah ditetapkan. Tapi juga sekaligus memicu kreativitas peserta didik serta mendekatkannya dengan teknologi yang sudah menjadi kebutuhan sehari-hari.

Langkah-langkah blended learning dengan aplikasi Whatsapp yaitu: 
1) Pada awal pertemuan perkuliahan akan disampaikan kepada peserta didik desain aktivitas pembelajaran yang akan dilakukan. Dalam tahap ini akan diberi tahukan bahwa pembelajaran dilakukan dengan dua aktivitas, yaitu face to face learning dengan metode diskusi presentasi yang dilaksanakan setiap minggu sekali dan online learning dengan metode diskusi. Bentuk aktivitas face to face, yaitu dengan membagi peserta didik menjadi beberapa kelompok kecil yang ditugaskan untuk membuat makalah sesuai tema yang ditentukan dan kemudian akan dipresentasikan serta didiskusikan di dalam kelas. Aktivitas kedua, yaitu aktivitas online learning yang menggunakan aplikasi Whatsapp sebagai media utama pendukungnya. Aktivitas online ini dilaksanakan untuk menguatkan dan juga memperdalam materi pembelajaran yang telah disampaiakan pada sesi face to face learning sebelumnya. Desain aktivitas yang dilakukan yaitu pengajar akan membentuk sebuah grup whatsapp yang anggotanya adalah seluruh peserta didik yang dijadikan kelas eksperimen. Peserta didik akan diberikan tema dan diharuskan memberikan tanggapan sesuai pemikiran dan sikapnya terhadap tema tersebut. Presensi pembelajaran online tersebut ditentukan apabila peserta didik sudah menanggapi tema yang diberikan. Dalam grup Whatsapp peserta didik juga diberikan kebebasan untuk mengangkat tema atau pertanyaan bagi anggota grup yang lain (baik pengajar atau teman sekelasnya) selama tema yang diangkat dan pertanyaan yang diajukan bersesuaian dengan materi pembelajaran. Peserta didik tidak diperkenankan sharing info, video, gambar, berita dan segala hal yang tidak relevan dengan materi pembelajaran. Peserta didik juga diberikan kebebasan berekspresi dan berkreasi dalam menanggapi tema yang diangkat sejauh dilakukan dengan sopan dan jauh dari tema SARA. Hal ini dilakukan agar diskusi grup whatsapp dapat berjalan kondusif dan terfokus pada tujuan pembelajaran dan di sisi lain, kenyamanan berdiskusi tetap dapat diwujudkan.

2) Setelah tata cara pembelajaran blended learning disampaikan, selanjutnya pengajar dapat menyampaikan pengantar mata kuliah desain pembelajaran agar peserta didik memiliki gambaran umum mengenai mata kuliah tersebut. Aktivitas ini dilakukan dengan metode ceramah dengan memberikan proyeksi utuh materimateri yang akan dibahas dalam seluruh perkuliahan nantinya. Peserta didik juga diberitahukan urgensi mempelajari mata kuliah serta memotivasinya agar mampu mencapai kompetensi-kompetensi yang diharapkan.

3) Pada tahap selanjutnya, yaitu saat pembelajaran face to face berlangsung. Pengajar hanya memfasilitasi dan mengamati proses pembelajaran diskusi presentasi yang sedang berlangsung. Setalah itu, pengajar menyampaikan materi 
yang belum tercover pada saat diskusi maupun presentasi, merangkum seluruh masukan dari peserta didik, dan menjawab pertanyaan-pertanyaan yang belum terjawab pada saat diskusi berlangsung. Aktivitas face to face learning ini dilaksanakan di ruang kelas sesuai jadwal perkuliahan yang ditentukan perguruan tinggi.

4) Aktivitas selanjutnya yaitu dengan pembelajaran online. Aktivitas ini dilaksanakan sekitar 2 hari setelah dilaksanakannya pembelajaran face to face. Dalam memulai pembelajaran online, pengajar mengangkat sebuah tema yang disampaikan dalam grup Whatsapp yang telah dibentuk sebelumnya kemudian seluruh peserta didik harus harus menanggapi tema-tema tersebut. Tema yang diberikan yaitu berbentuk sebuah video yang terkait dengan materi pembelajaran dan diajukan sebuah pertanyaan yang harus dijawab peserta didik berdasarkan video yang disampaikan dan materi pembelajaran yang telah disajiikan pada saat face to face learning. Jadi, online learning dimaksudkan selain memperkuat materi perkuliahan juga sebagai pendalaman dari materi tersebut. Aktivitas online learning yang dilaksanakan juga lebih bersifat diskusi jika nantinya ada pertanyaan yang masih belum mengarah pada jawaban. Sebab pertanyaan yang diberikan bukanlah pertanyaan dengan jawaban benar salah. Akan tetapi, pertanyaan yang mempertanyakan sikap, wawasan dan pemikiran peserta didik. Oleh karenanya, semua jawaban dianggap benar dalam tingkat tertentu selama sudah sesuai dengan maksud pertanyaan dan topik yang dibahas. Ketika peserta didik telah menanggapi maka pengajar hendaknya mengapresiasi jawaban yang telah diberikan secara langsung. Agar peserta didik tahu bahwa jawabannya sudah diterima pengajar dan mendapatkan apresiasi. Peserta didik tidak harus menjawab langsung pertanyaan yang diberikan, tapi diberi keleluasaan waktu sekitar 3-4 hari untuk menjawabnya. Mereka boleh mencermati terlebih dahulu pertanyaan yang diberikan dan mencari sumber-sumber informasi yang dijadikan dasar jawaban. Bisa juga peserta didik beraktivitas lainnya karena tidak terikat ruang dan waktu.

5) Setelah batas waktu yang diberikan dalam menanggapi pertanyaan selesai, yaitu sekitar 3-4 hari. Maka pengajar baru merangkum seluruh jawaban yang masuk disertai penjelasan yang lengkap dan mendalam disertai dasar logis, valid dan rasional. Rangkuman yang diberikan juga hendaknya menyimpulkan seluruh materi pembelajaran yang telah disampaikan. Di samping itu, rangkuman penjelasan yang disampaikan juga harus bersesuaian dengan rumusan tujuan pembelajaran yang telah ditentukan sebelumnya. 
6) Pembelajaran face to face dan online learning selanjutnya dilakukan secara bergantian dengan konsep yang sama setiap minggunya sampai seluruh topik perkuliahan yang direncanakan tersampaikan secara keseluruhan.

7) Pengajar memberikan evaluasi formatif terhadap jalannya proses pembelajaran, yaitu dengan menilai apa saja unsur-unsur pembelajaran yang kurang optimal baik dalam pembelajaran face to face maupun pembelajaran online. Hasil analisis evaluasi formatif selanjutnya dijadikan pertimbangan dalam perbaikan proses pembelajaran berikutnya.

8) Setelah itu, aktivitas terakhir yaitu dengan memberikan evaluasi sumatif yang dimaksudkan untuk melihat sejauh mana tercapainya tujuan pembelajaran bagi setiap peserta didik. Evaluasi ini dilaksanakan dengan menggunakan instrumen penilaian soal uraian. Instrumen yang diberikan hendaknya sudah dianalisis dan diujikan sebelumnya, sehingga memiliki validitas dan reliabilitas yang dapat dipertanggungjawabkan, yaitu mengukur apa yang seharusnya diukur dan memiliki konsistensi serta tingkat kepercayaan yang handal dalam mengukur tercapainya kompetensi yang telah ditentukan.

\section{Media pembelajaran yang digunakan dalam blended learning.}

Dalam mendesain pembelajaran, Ketika seorang pengajar telah melakukan analisis karakteristik dan kebutuhan peserta didik, merumuskan tujuan pembelajaran, mengembangkan materi pembelajaran dan menetapkan aktivitas dan metode pembelajaran yang sesuai dalam rangka pencapaian tujuan pembelajaran, maka pengajar juga harus menentukan media apa yang dipakai dalam mendukung proses pembelajaran tersebut. Media tersebut dapat memiliki beraneka macam bentuk seperti media cetak (seperti buku teks, kertas gambar, atau LKS), media audiovisual (seperti film, video atau slide power point), media interaktif seperti software atau aplikasi, atau kombinasi dari ketiga media tersebut.

Media pembelajaran yang digunakan dalam pembelajaran blended learning, antara lain yaitu:

a. Software/aplikasi Whatsapp sebagai media untuk berdiskusi dalam online learning.

b. Smartphone digunakan sebagai hardware untuk instalasi aplikasi Whatsapp.

c. Paper digunakan untuk acuan presentasi yang berbentuk makalah.

d. Perangkat LCD Proyektor beserta komputer jinjing (laptop) sebagai media pendukung face to face learning dengan strategi diskusi-presentasi. 
e. Aplikasi Slide Power point sebagai media pendukung presentasi pada pembelajaran face to face.

f. Video pembelajaran yang digunakan dalam online learning sebagai pendukung tema diskusi yang harus ditanggapi.

g. Aplikasi videoshow yang digunakan sebagai editor video untuk smartphone android, yang bisa dipakai untuk memotong video, efek suara, pemberian teks pada video, mempercepat/menambah durasi, efek gambar, compressing size, penggabungan beberapa video dan lain-lain.

h. Portal web online seperti (seperti google cendikia atau wikipedia), portal berita online (seperti detiknews.com, tempo.co, Kompas.com) atau video online (youtube.com), blog (worpress atau blogspot).

Media yang digunakan di atas memegang peranan kunci dalam mendukung aktivitas pembelajaran blended learning agar berjalan dengan baik. Khusus pada media pembelajaran yang berbentuk program software/aplikasi, Alessi dan Trollip menyampaikan bahwa "Although there is much research in learning and instruction to guide us in developing instruction, the best guarantee that a program will be effective is to try it out, revise it, try it again, and so on until you get it right". ${ }^{19}$ Jika merujuk pada pertimbangan tersebut tentunya media-media yang telah ditentukan di atas haruslah diuji coba dahulu kinerjanya, kemudian direvisi, diuji coba lagi sampai media tersebut benar-benar siap dipakai dalam pembelajaran nantinya.

\section{Evaluasi pembelajaran blended learning}

Proses penting lainnya dalam desain pembelajaran, yaitu menentukan bagaimana tingkat keberhasilan proses pembelajaran dalam mencapai tujuan yang diharapkan. Hal itu dapat diketahui dengan adanya evaluasi pembelajaran yang diartikan sebagai proses pengumpulan dan pengelolaan informasi untuk mengukur pencapaian hasil belajar peserta didik ${ }^{20}$. Tingkat keberhasilan harus dapat diukur dan diamati (measurable and observable) pada setiap level dan aspek yang berbeda melalui sebuah proses sistematis. Berbagai jenis evaluasi yang dilakukan akan membantu menunjukkan bahwa semua aktivitas yang telah dilakukan dalam pembelajaran telah sesuai dengan kebutuhan setiap peserta didik. Dengan kata lain

\footnotetext{
${ }^{19}$ S. M. Alessi, \& S. R Trollip, Multimedia for learning: Methods and development. (Boston: Allyn \& Bacon, 2001), 54.

20 Peraturan Pemerintah Republik Indonesia Nomor 19 Tahun 2005 tentang Standart nasional Pendidikan Pasal 1 (Bandung: Nuansa Mulia, 2008), 90.
} 
bahwa aktivitas pembelajaran telah tepat sasaran dalam pencapaian tujuan pembelajaran yang telah ditentukan.

Terdapat dua hal yang memiliki keterkaitan erat dalam pembahasan mengenai evaluasi, yaitu penilaian dan pengukuran. Penilaian merupakan langkah atau teknik dalam menyimpulkan data tentang peserta didik atau hasil belajar. Sedangkan pengukuran merupakan suatu kegiatan menentukan kuantitas suatu objek melalui aturan-aturan tertentu sehingga kuantitas yang diperoleh benar-benar mewakili sifat dari suatu objek yang dimaksud.

Berdasarkan penjelasan di atas maka evaluasi dapat diartikan sebagai proses untuk menentukan tingkat keberhasilan berdasarkan pada data yang telah dikumpulkan dan kemudian membuat keputusan berdasarkan pada tingkat keberhasilan tersebut. ${ }^{21}$ Jenis evaluasi antara lain yaitu evaluasi formatif dan evaluasi sumatif. Prof. Sunardi menganalogikan bahwa perbedaan evaluasi formatif dan sumatif yaitu seperti perbedaan saat seorang chef restoran memasak suatu masakan. Evaluasi formatif layaknya penilaian makanan sebelum makanan itu disajikan. Sedangkan evaluasi sumatif yaitu penilaian makanan setelah makanan tersebut dihidangkan (analogi ini disampaikan pada saat penulis berada di bangku perkuliahan pascasarjana). Hal itu berarti bahwa, penilaian formatif merupakan penilaian di tengah proses pembelajaran untuk menentukan apakah proses pembelajaran berlangsung sesuai yang diharapkan atau adakah kendala yang dihadapi untuk kemudian dapat diperbaiki sebelum pembelajaran selesai dilaksanakan. Berbeda halnya dengan evaluasi sumatif, yang merupakan penilaian terhadap tingkat keberhasilan yang dicapai proses pembelajaran dalam mencapai tujuan pembelajaran.

Evaluasi yang dilakukan dalam blended learning dilakukan melalui dua aspek, yaitu evaluasi formatif dan evaluasi sumatif. Evaluasi formatif dilakukan pada setiap langkah-langkah pembelajaran selama proses belajar berlangsung. Evaluasi ini tidak hanya ditujukan pada tingkat pemahaman sementara peserta didik, tapi juga evaluasi proses pembelajaran yang telah dilakukan. Apakah ada unsur pembelajaran yang memiliki kinerja yang tidak maksimal, atau apakah ada hal-hal yang menghambat jalannya proses pembelajaran. Segala hal yang tidak diinginkan yang ditemukan dalam evaluasi formatif selanjutnya diperbaiki dan disempurnakan agar proses pembelajaran selanjutnya dapat berlangsung lebih optimal.

Evaluasi sumatif pada pembelajaran blended learning dilakukan untuk mengukur dua aspek, yaitu aspek peserta didik dan aspek proses pembelajaran. Evaluasi sumatif terhadap peserta didik dimaksudkan untuk mengetahui bagaimana

${ }^{21}$ Anas Sudjono, Pengantar Evaluasi Pendidikan (Jakarta: Raja Grafindo Persada, 1998), 1-2. 
tingkat pemahaman peserta didik terhadap materi pembelajaran setelah seluruh proses pembelajaran dilaksanakan. Untuk mengetahuinya yaitu dengan mengumpulkan data hasil belajar yang diperoleh dari tes yang diberikan kepada peserta didik setelah seluruh materi pembelajaran disampaikan. Tes yang digunakan dalam proses evaluasi yaitu berbentuk soal esai. Evaluasi bentuk ini sangat sesuai untuk menentukan kemampuan kognitif tingkat tinggi peserta didik (seperti kemampuan sintesis dan analisis).

Instrumen pengumpul data hasil belajar yang diberikan kepada peserta didik, haruslah memiliki validitas dan reliabilitas dalam mengukur hasil belajar yang dicapai peserta didik. Untuk memastikan validitas dan reliabilitasnya, instrumen penelitian hendaknya diuji coba terlebih dahulu kepada kelompok lain dalam populasi yang sama selain kelompok sampel penelitian.

Evaluasi sumatif juga dimaksudkan untuk mengetahui bagaimana tingkat keberhasilan proses pembelajaran yang telah didesain sebelumnya dalam mewujudkan pencapaian tujuan pembelajaran yang diharapkan. Hal ini dilakukan untuk menilai berbagai aspek desain pembelajaran seperti evaluasi analisa karakteristik dan kebutuhan peserta didik, evaluasi rumusan tujuan pembelajaran, evaluasi pengembangan materi pembelajaran, evaluasi media dan strategi yang digunakan, bahkan evaluasi instrumen evaluasi itu sendiri. Evaluasi dalam hal ini tidak perlu diwujudkan dalam sebuah nilai tertentu, akan tetapi lebih dijadikan sebagai catatan yang dapat dipertimbangkan untuk proses pembelajaran dengan tujuan yang berbeda lainnya.

\section{Penutup}

Blended learning senantiasa menjadi kajian menarik terutama sekali jika dipadukan dengan konteks perkembangan ICT yang begitu pesat. Unsur online learning yang ada pada blended learning akan turut berkembang juga tidak hanya pada perpaduannya dengan metode pembelajaran digital, namun lebih detail lagi pada aktivitas pembelajaran, media pembelajaran sampai pada evaluasi pembelajarannya. Gambaran aktivitas pembelajaran blended learning dalam artikel ini hanya mencakup satu model saja. Masih banyak model lain yang bisa diterapkan. Kajian lebih kritis dan lengkap ataupun kajian mengenai penerapan blended learning dengan menggunakan model lain, tentunya akan semakin memperkaya keilmuan mengenai blended learning.

Dalam penerapan aktivitas pembelajaran dan pemilihan media pembelajaran hendaknya tetap menyesuaikan konteks lingkungan yang ada dalam pembelajaran. Tidak memaksakan aktivitas dan metode tertentu menjadi langkah bijak dalam 
menghadirkan pengalaman belajar bagi peerta didik. Hal itu dikarenakan tidak adanya satu pun metode yang dapat digunakan untuk semua kondisi. Kesederhanaan aktivitas dan media pembelajaran yang ditawarkan dalam artikel ini semata-mata dikarenakan konteks lingkungan yang dihadapi banyak praktisi pendidikan saat ini.

\section{Daftar Pustaka}

Ahmad, Al-Huneidi. Constructivism Based Blended Learning in Higher Education, Tesis, Wetenschappen: Universiteit Hasselt Faculteit Toegepaste Economische. 2010.

Alessi, S. M. \& Trollip, S. R Multimedia for Learning: Methods and Development. Boston: Allyn \& Bacon. 2001.

Avgerinou, Maria D. Blended Collaborative Learning for Action Research Training. Journal of Open Education, Vol 4, No.1 (2008), 88.

Bohle-Carbonell, K. dkk. Supporting learner engagement through Problem-based learning: Institutional and instructional implications. In P. Blessinger \& C. Wankel (Eds.), Increasing student engagement and retention in e-learning environments: Web 2.0 and blended learning technologies (Vol. 7). (NY: Emerald, 2013).1-15

Bonk dan Graham, Handbook of Blended Learning: Global Perspective, Local Design. Cheicester: John Wiley. \& Sons Inc. 2004.

Bonk, C. J. Olson, T. M. Wisher, R. A. \& Orvis, K. L. Learning from Focus Groups: An Examination of Blended Learning. Journal of Distance Education, Vol. 17, No.3 (2002), 97-118.

Carr-Chellman, A. Dyer, D. \& Breman, J. Burrowing through the Network Wires: does Distance Detract from Collaborative Authentic Learning? Journal of Distance Education, Vol.15. No.1. 2000, 39-62.

Collins Mauri, dan Berge, Zane. Facilitating Interaction in Computer Mediated Online Course. Proceedings of the FSU/AECT Conference on Distance Learning . Juni 20-23, Tallahassee, Florida.

Dziuban, C. D. Hartman, J. L. \& Moskal, P. D. Blended Learning. Educause Center for Applied Research: Research Bulletin, (2004, March 30), 1-12, diunduh dari http://net.educause.edu/ir/library/pdf/ERB0407.pdf .; 
Garrison, Randy. dan Kanuka, Heather. Blended Learning: Uncovering its Transformative Potential in Higher Education. Internet and Higher Education Journal. Vol 7 No. 2, 2004, 95-105.

Kaur, A. \& Ahmed, A. Open Distance Pedagogy: Developing a Learning Mix for the Open University Malaysia. In C. Bonk \& C. Graham (Ed.), The Handbook of Blended Learning. San Francisco, CA: Pfeiffer. 2005.

Keller, J. B. Ehman, L. H. \& Bonk, C. Professional Development that Increases Technology Integration by K-12 Teachers: Influence of the TICKIT Program. Paper presented at the annual meeting of the American Educational Research Association. San Diego: CA. 2004.

Peraturan Pemerintah Republik Indonesia Nomor 19 Tahun 2005 tentang Standart nasional Pendidikan Pasal 1. Bandung: Nuansa Mulia. 2008.

Robinson, Rhonda. dkk. "Facilitating Learning", dalam Educational Technology: A Definition with Commentary (ed.), Alan Januszewski dan Michael Molenda. New York: Taylor \& Francis Group. 2008.

Seife, C. Zero: The Biography of a Dangerous Idea. New York: Penguin Books. 2000.

Senge, P. M. The Fifth Discipline: The Art and Practice of the Learning Organization. New York: Doubleday. 1990.

Sharpe, R. Benfield, G. Roberts, G. \& Francis, R. the Undergraduate Experience of Blended e-Learning: a Review of UK Literature and Practice. The Higher Education Academy, Diunduh dari http://www.heacademy.ac.uk/assets/documents/research/literature_reviews/blende d_elearning_exec summary 1.pdf.

Sudjono, Anas. Pengantar Evaluasi Pendidikan. Jakarta: Raja Grafindo Persada. 1998.

Vaughan, N. Perspectives on Blended Learning in Higher Education. Internasional Journal on E-Learning. Vol. 6, No.1 (2007), 81-94. 